\section{Exercise-induced diastolic abnormalities in Type 1 (insulin-dependent) diabetic patients without overt heart disease}

\section{Dear Sir}

In a recent publication, Uusitupa and coworkers [1] reported on findings of the left ventricular diastolic (and systolic) functions in middle-aged diabetic patients free of cardiovascular disease. A decreased peak diastolic filling rate was found in women but not in men with Type 1 (insulin-dependent) diabetes mellitus compared to control subjects while isovolumic relaxation time and the height of the A wave/the total amplitude of apex cardiogram $(\mathrm{A} / \mathrm{H})$ ratio were normal in these patients. Diastolic abnormalities could be also documented in patients with Type 2 (non-insulin-dependent) diabetes mellitus. In contrast to this study and some other [2-4] evaluating only resting left ventricular diastolic (and systolic) functions in diabetic patients, we carried out a non-invasive cardiac investigation for assessing the exercise-induced diastolic abnormalities in patients with Type 1 diabetes.

Twenty-seven patients (14 women and $13 \mathrm{men}$ ) with Type 1 diabetes were selected for the investigations. Their age ranged between 18 and 43 years (mean: 34.2 years) with a duration of diabetes from 1 to 25 years (mean: 9.8 years). None of them had any clinical, electrocardiographic or X-ray evidence of heart disease, and arterial blood-pressure was also within the normal range. All patients were on conventional insulin therapy without laboratory signs of ketoacidosis. Patients with ethanol abuse and those receiving drugs which might affect cardiac performance were excluded. Patients with proliferative retinopathy were not selected for dynamic exercise, however, background retinopathy was observed in 16 patients. Only borderline cases of cardiac autonomic neuropathy were detected in 7 patients. Fifty age- and sex-matched healthy individuals served as control subjects.

ECG, phonocardiogram, apexcardiogram and carotid pulse were registered at rest and after symptom-limited, graded dynamic exercise on a bicycle ergometer. Apexcardiograms were numerically digitized for measurement of amplitude-parameters and time intervals
[5]. The diastolic time intervals (early apexcardiographic relaxation time, isovolumic relaxation period, total apexcardiographic relaxation time) were corrected to the heart rate according to the Bazettformula while amplitude-parameters of contraction and relaxation were normalized [6]. The ratio of pre-ejection period to left ventricular ejection time (PEP/LVET) and $\mathrm{A} / \mathrm{H}$ ratio were directly measured.

Comparing the diabetic and control groups, the mean values of time intervals and amplitude-parameters did not differ considerably at rest (data not shown). After dynamic exercise, the early apexcardiographic relaxation time was higher while normalized amplitude of relaxation was lower in the diabetic group than in the control subjects (Table 1). These alterations refer to abnormalities involved in the early relaxation of the left ventricle of patients with Type 1 diabetes. No correlation could be found between the diastolic abnormalities and the metabolic state assessed by blood glucose, glycated haemoglobin and serum fructosamine values.

We concluded that testing of left ventricular performance by digitized apexcardiography after dynamic exercise in patients with Type 1 diabetes might be used for detecting diastolic abnormalities even when no alterations could be identified at rest. Our results are in agreement with a recent publication [7] where an abnormal peak rate of dimension increase was found during exercise (and at rest) on digitized M-mode echocardiography in young, long-term Type 1 diabetic men. Furthermore, our results are in agreement with the view $[2,3]$ that signs of diastolic abnormalities could appear earlier than those of systolic in patients with Type 1 diabetes.

Yours sincerely,

Gy.Jermendy, S. Khoór, M.Z. Koltai and G. Pogátsa

\section{References}

1. Uusitupa M, Mustonen J, Laakso M, Vainio P, Länsimies E, Talwar S, Pyörälä K (1988) Impairment of diastolic function in middleaged Type 1 (insulin-dependent) and Type 2 (non-insulin-dependent) diabetic patients free of cardiovascular disease. Diabetologia 31: 783-791

Table 1. Values of diastolic/systolic time intervals and amplitude-parameters measured by digitized apexcardiography in patients with Type 1 (insulin-dependent) diabetes after dynamic exercise

\begin{tabular}{|c|c|c|c|}
\hline & $\begin{array}{l}\text { Diabetic patients } \\
(n=27)\end{array}$ & $\begin{array}{l}\text { Control subjects } \\
(n=50)\end{array}$ & $\begin{array}{l}\text { Significance } \\
p \text { value }\end{array}$ \\
\hline Heart rate at registration $\left(\min ^{-1}\right)$ & $133 \pm 6$ & $136 \pm 2$ & NS \\
\hline $\begin{array}{l}\text { Systolic function } \\
\text { PEP/LVET } \\
\text { Normalized amplitude of contraction }\left(\mathrm{ms}^{-1}\right)\end{array}$ & $\begin{array}{l}0.283 \pm 0.023 \\
0.016 \pm 0.005\end{array}$ & $\begin{array}{l}0.279 \pm 0.032 \\
0.022 \pm 0.008\end{array}$ & $\begin{array}{l}\text { NS } \\
\text { NS }\end{array}$ \\
\hline
\end{tabular}

Results are expressed as mean $\pm \mathrm{SEM}$. Diastolic time intervals are corrected to the heart rate according to the Bazett-formula. $\mathrm{A} / \mathrm{H}$ ratio $=$ the height of the A wave/the total amplitude; $P E P=$ pre-ejection period; LVET=left ventricular ejection time 
2. Punzengruber C, Schernthaner G, Silberbauer K, Seebacher C (1986) Left ventricular function in well-controlled insulin-dependent (Type 1) diabetics an echophonocardiographic study. Cardiology 73: 132-138

3. Kahn JK, Zola B, Juni JE, Vinik AI (1986) Radionuclide assessment of left ventricular diastolic filling in diabetes mellitus with and without cardiac autonomic neuropathy. J Am Coll Cardiol 7: 1303-1309

4. Shapiro LM, Howat AP, Calter MM (1981) Left ventricular function in diabetes mellitus. In: Methodology, and prevalence and spectrum of abnormalities. Br Heart J 45: 122-128

5. Manolas J, Rutishauser W (1977) Relation between apex cardiographic and internal indices of left ventricular relaxation in man. $\mathrm{Br}$ Heart J 39: 1324-1332

6. Kékes E, Mihóczy L (1988) Mechanocardiography. In: Mihóczy L (ed) Non-invasive cardiac diagnosis. Akadémiai Kiadó, Budapest, pp $190-237$

7. Danielsen R, Nordrehaug JE, Vik-Mo H (1988) Left ventricular diastolic function in young long-term Type 1 (insulin-dependent) diabetic men during exercise assessed by digitized echocardiography. Eur Heart J 9: 395-402

Dr. Gy.Jermendy

Merényi Hospital

Gyáli ut 17-19

H-1097 Budapest

Hungary

\section{Left ventricular function in diabetes mellitus}

\begin{abstract}
Dear Sir,
In reply, to the letter from Dr. Jermendy dealing with our results on left ventricular diastolic abnormalities in patients with Type 1 (insulin-dependent) and Type 2 (non-insulin-dependent) diabetes [1], we do agree that evaluating left ventricular function during or after exercise may provoke some diastolic and systolic abnormalities in diabetic patients in whom left ventricular function at rest may be quite normal. We also agree with the opinion of Jermendy that diastolic function abnormalities may appear earlier than systolic dysfunction in the clinical course of diabetic heart muscle disease.

We performed an exercise radionuclide angiocardiographic study on our diabetic patients who had no evidence of ischaemic heart disease [2]. With the exception of 4 diabetic men, all other diabetic patients had normal systolic function at rest but an impairment of left ventricular systolic function during exercise was not an uncommon finding in different diabetic groups; the frequency ranging from 42 to $71 \%$. Left ventricular ejection fraction after peak exercise was similar or even higher in diabetic patients than in control subjects. These findings emphasize also that exercise may provoke left ventricular function abnormalities and, on the other hand, diastolic abnormalities in left ventricular function may occur earlier and even at rest while no apparent abnormalities can be noted in systolic function. Unfortunately, the radionuclide angiocardiographic method in our study
\end{abstract}

could not be used for the close evaluation of left ventricular diastolic function either at rest, or during and after exercise [2]. As to the method used by Dr. Jermendy, it is cheap, noninvasive and easy to perform but, on the other hand, it should be remembered that it is an indirect method and, thus, has its limitations in evaluating left ventricular diastolic function.

In all, there is now a great deal of evidence that both Type 1 and Type 2 diabetic patients may have abnormalities in diastolic and systolic function. The degree and frequency of these abnormalities are dependent on the selection of patients and the methods used for evaluation of left ventricullar function. Further studies should be concentrated to resolve the background of these abnormalities as well as their clinical significance in the long-term. In this context, we would like to emphasize that diabetic autonomic neuropathy may contribute to diastolic function abnormalities [1,3], and therefore the impact of autonomic neuropathy should be taken into account in analyses. Unfortunately, the methods used for detection of autonomic nervous dysfunction are too crude to diagnose early abnormalities. There is also suggestive evidence from clinical studies that metabolic factors may contribute to an impaired left ventricular function in diabetic patients, and thus, some of the abnormalities in left ventricular function in diabetes may be reversible $[4,5]$.

Yours sincerely,

M. Uusitupa and J.Mustonen

\section{References}

1. Uusitupa M, Mustonen J, Laakso M, Vainio P, Länsimies E, Talwar S, Pyörälä K (1988) Impairment of diastolic function in middleaged Type 1 (insulin-dependent) and Type 2 (non-insulin-dependent) diabetic patients free of cardiovascular diseases. Diabetologia 31: 783-791

2. Mustonen J, Uusitupa M, Tahvanainen $\mathrm{K}$, Talwar S, Laakso $M$, Länsimies E, Kuikka J, Pyörälä K (1988) Impairment of left ventricular systolic function during exercise in middle-aged insulin-dependent and non-insulin-dependent diabetic subjects without clinically evident cardiovascular disease. Am J Cardiol 62: 1273-1279

3. Kahn JK, Zola B, Juni JE, Vinik AJ (1986) Radionuclide assessment of left ventricular diastolic filling in diabetes mellitus with and without autonomic neuropathy. J Am Coll Cardiol 7: 1303-1308

4. Uusitupa M, Siitonen O, Aro A, Korhonen T, Pyörälä K (1983) Effect of correction of hyperglycemia on left ventricular function in non-insulin-dependent (Type 2) diabetics. Acta Med Scand 213: 363-368

5. Mustonen J, Laakso M, Uusitupa M, Sarlund H, Pyörälä K, Rautic P, Kuikka J, Länsimies E (1988) Improvement of left ventricular function after starting insulin treatment in patients with noninsulin-dependent diabetes. Diab Res 9: 27-30

Dr. M.Uusitupa

Department of Clinical Nutrition

University of Kuopio

PO Box 6

SF-70211 Kuopio

Finland 